\title{
The Quality of Bank-Provided Investment Consulting Service for Private Individuals in Estonia
}

\author{
Kantšukov Mark and Štšukina Maria
}

\begin{abstract}
In this paper we assess the quality of investment consulting service for private individuals provided by Estonian commercial banks. The study is based on content analysis of websites of commercial banks, and (staged) interviews with investment consultants in main Estonian banking institutions. We find that investment consulting service in Estonian banks is not on appropriate level compared to developed markets, and there is a significant room for improvement. However, severity of particular problems related to investment consulting service varies by institution.
\end{abstract}

Index Terms-Customer protection, financial sector, investment consulting, retail banking.

\section{INTRODUCTION}

After the outbreak of the financial crisis of 2007-2008 in the US, which later transformed into the global economic crisis, a lot of debating has been taking place regarding tightening of monitoring of financial sector, reversal of the process of deregulation of financial markets. Financial markets develop very fast, and many financial products have become more complex, opaque, less comprehensible, especially for individual investors. This was clearly demonstrated by the rearmost global crisis: aside of uncontrolled lending there were breaches and abuses in the field of investment, including investment consultation (advisory).

Usually private individuals are less informed about the situation on financial markets; they do not have sufficient knowledge about finance and investment. That is why services of investment consultants working in commercial banks, their asset management divisions or other institutions become especially important. The authors of the present paper see the objective of investment consultants in determining the best investment solution for their customers taking into account customers' personal goals, risk tolerance, length of investment horizon etc.

Malicious practice of investment services was felt by economy of Estonia both indirectly (through the impact of the global financial crisis) and directly (through infringements that had taken place in Estonian banking sector). The praxis of investment consultation in Estonia is relatively young; investment consulting related systems must be perfected by banks and regulatory bodies using instruments created in

Manuscript received July 20, 2013; revised October 9, 2013

Mark Kantšukov is with the University of Tartu, Faculty of Economics and Business Administration, Narva road 4, Tartu 51009, Estonia (e-mail: ecomark@ut.ee).

Maria Štšukina is with Electrolux Europe, Brussels, Belgium (e-mail: maria.stsukina@electrolux.be). countries with developed financial markets as example.

Investment consultation is an efficient mean. Professional advice fosters the creation of a favorable investment environment for private individuals, increases their financial consciousness and generally is beneficial for country's economic development. Consultation of inferior quality undermines the trust towards financial system and overall may be harmful for the economy.

The necessity for high-quality investment advisory is considered in many studies, but in case of Estonia there are too little data, and only few adequate studies. Results of studies on the quality of advisory services generally are not available as these studies were conducted by supervision authorities, and they contain confidential information [1], [2], [3]. There are some assessments of the quality of investment advisory given by investigative journalists (e.g. [4]) but these were not carried out according to formalized approach.

The aim of this paper is to assess the quality of investment consulting services provided for private individuals by commercial banks operating in Estonia. Commercial banks are selected due to the fact that these institutions provide investment consulting service to aforementioned customers. The models developed in [5] and [6] are used to assess the quality; from these models the most important attributes of investment consulting service have been taken into use assurance, reliability, access, flexibility and professional skills. As named components are reflected in international ethical standards of investment consultation and national legal acts, the quality of investment consulting in Estonia is assessed based on them.

The paper is structured as follows. First of all, we consider role and importance of investment consulting service for private individuals. Then we present approaches to investment consultation quality assessment. This part is followed by description of data and methodology, and results of empirical analysis. We complete the paper with conclusions and propositions to improve the quality of investment consulting service in Estonian commercial banks.

\section{INVESTMENT CONSULTATION OF PRIVATE INDIVIDUALS - A GENERAL FRAMEWORK}

There are several parties in investment consulting process; each party has its own interests. That is why in order to understand the role of investment consulting it is important to observe this process from the standpoint of each party (or interest group). There are four partakers directly or indirectly participating in investment consultation:

1) Government institutions (generally - state) that regulate and monitor investment advisory service. 
2) A commercial bank that offers investment consulting service.

3) An investment consultant that provides investment advisory service.

4) An investor consuming investment advisory service.

Investment consulting process and behavior of participants is influenced by economic, ethical and legal factors which in turn affect the quality of the service (see Fig. 1 below).

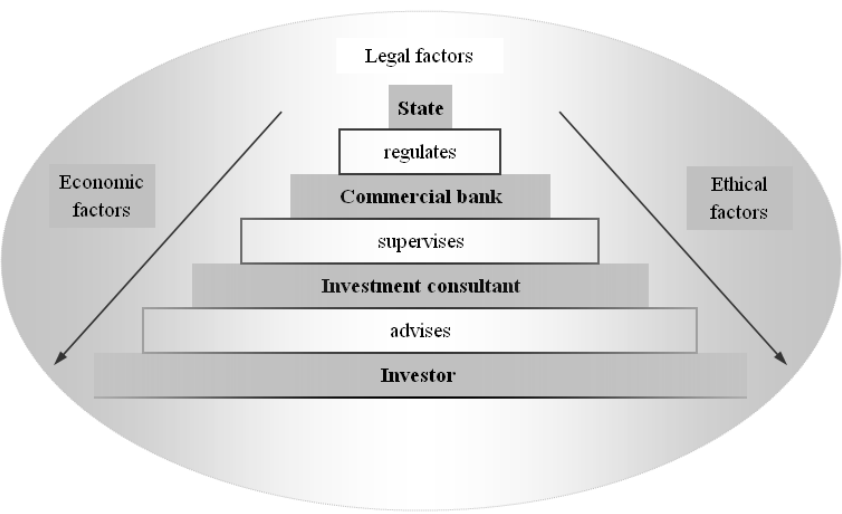

Fig. 1. Participants in investment consulting process.

Under economic factors interests of investment consulting process participants can be considered (as these interests lay mostly within economic sphere). An investor (customer) tries to maximize his/her well-being and the value of capital. Motives of an investment consultant are related with his/her remuneration. A bank seeks to increase its revenues by selling investment products and services. People's activeness on financial markets also stimulates in one way or another economic activity in general which is also positive from governmental point of view.

The state is interested in economic stability which can be jeopardized in case of pernicious practice of investment consulting. Uncontrollable abuse of customers' reliance may cause intractable fluctuations [7]. Malicious praxis was one of the causes of economic crisis of 2007-2008 [8], [9]. That is why government bodies regulate through legal acts provision of investment services and monitor the investment consulting service provider. From the state perspective it is also important to educate private individuals in investment issues and increase people's awareness.

Ethical factors influence primarily behavior of a bank as an organization and investment consultants. Through the behavior of the bank's representatives these factors affect also customer's perception of investment consulting service. The functioning of financial markets is largely based on investors' trust which stems from vigilant implementation of ethical principles by market participants. Ethical responsibility begins with self-imposed control - individual behavior of employees and financial market participants followed by corporate codes and procedures and national or sectoral ethical regulations [10].

Legal factors refer to legal acts and standards that regulate the process of investment consulting and behavior of participants. Their purpose is to provide servicing of real economy by financial markets, increase market efficiency, longevity and transparency [11]. Legal acts that regulate investment consulting do not assure competence, they are intended for investor protection from fraud and unethical practice [12]. As a measure legal acts work most efficiently against malicious practice as latter is liable to prosecution.

As previously mentioned factors affect the process of investment consultation then they certainly have the impact on the quality of investment advisory service. This in turn leads us to possibilities, or approaches, to investment consultation quality assessment.

\section{APPROACHES TO INVESTMENT CONSULTATION QUALITY ASSESSMENT}

High-class investment consultation service is important not only from the point of view of a private investor, it is also important for creating good reputation for an investment consultant, building credibility and loyalty towards a commercial bank. It also important on macroeconomic level as proficient investment advisory helps to keep economic agents' trust in financial markets. As the aspect of the quality is so important, the essence of the quality in investment consultation should be clarified; also one must apply an appropriate method to measure quality.

General definition of quality refers to completeness of properties and functions of product or service that carries the ability to satisfy direct or indirect needs [13]. Parasurman, Zeithaml, and Berry (1988) define perceived quality of service as "a global judgment, or attitude, relating to the superiority of the service" [6]. In case of investment services the quality has been defined as investor's perception of achieved satisfactory returns under acceptable and generally accepted risks within planned period of time [14].

Grönroos (1998) differentiated between technical and functional qualities of service; he also took into account the impact of company's image on assessment of the functional and technical quality. Functional quality refers to quality of service provision process - i.e. how the service is provided. Technical quality refers to outcome quality - i.e. what the service finally offers to a client. Technical quality determines acceptability of the service for a client. Grönroos (1998) mentioned the following components of assessment of functional quality assessment: professional skills, service attitude and behavior, availability, assurance and credibility, compensation, reputation and persuasion [5].

Further research confirmed its validity, and also demonstrated that functional quality of services has higher impact vis-à-vis technical quality in institutions that provide services with high credence properties [15]. Examples of such services are healthcare, legal aid and investment advisory [16].

Another approach to service quality assessment arises mainly from Parasurman, Zeithaml, and Berry (1985), according to which service quality can be assessed based on dimension of functional or process quality that can be characterized by certain components. In paper by Parasurman, Zeithaml, and Berry (1985) authors brought out 10 criteria to determine quality of the service: reliability, responsiveness, competence, access, courtesy, security, understanding/knowing the customer, and tangibles [17]. 
Later the number of components was decreased to five, most important: reliability, responsiveness, assurance, empathy and tangibles [6]. Later this approach was criticized by Cronin and Taylor (1994) who elaborated alternative measurement method [18].

In her research Ouyang (2010) came to conclusion that financial consulting service is directly positively related with credence and indirectly with customer's loyalty. It was also confirmed that service quality plays an important role in relations between a client and a company. When quality of the service is high the clients perceive that $\mathrm{s} / \mathrm{he}$ is being taking care of. In order to satisfy clients' wants investment consultants need more competence to specify customers' problems [9].

Welch's (2003) approach to investment consultation quality assessment implies appraisal of an adviser's performance. According to this approach, the adviser has to offer a private investor objectivity, expert opinion, discipline, availability, education, and service. The most critical component is the service itself but everything the adviser does is induced by these six properties. Another important aspect is whether the adviser and the bank are investment or customer centered. Customer-centered banks have higher customer keeping ratio compared with investment-centered banks. Thus, attention paid to customers plays a great role in assessment of the quality of the service [19]. Customer-centered approach and the quality of communication are considered to be especially important in times of economic crisis as they shape customer's perception of service and trust [20].

In authors' opinion, both models of C. Grönroos and A. Parasurman, V. A. Zeithaml, and L. L. Berry are suitable for assessing functional quality of investment consulting service, thereby the most important component seems to be assurance and reliability, professional skills, availability and flexibility.

The most convenient way to measure the process quality of investment consulting service is by following codes of ethics and legal acts as they include given component in the form of standards and rules. The most important component is reliability - the majority of standards and legal acts directed towards malicious practices are based on reliability.

\section{DATA AND METHODOLOGY}

In order to assess the quality of investment consulting service provided by commercial banks one must determine which banks provide such a service (and which institutions have authorized permit for that activity). Based on the information from Financial Supervision Authority of Estonia the pool of six commercial banks was formed. It consisted of the following institutions: AS Swedbank, AS SEB Pank, Nordea Pank Finland plc Eesti, AS Danske Capital Sampopank, and AS LHV Pank. It has to be mentioned that as of 31.12.2012 AS Swedbank Investeerimisfondid (which is a part of the Swedbank Group) had the largest market share among Estonian investment funds in terms of value of assets under management $-43 \%$. The second largest player on a market is AS SEB Varahaldus (affiliate of AS SEB Pank) which had 22\% market share [21]. As one can see, Estonian market for investment funds is very concentrated, and is dominated by couple of asset management institutions.

Our analysis is twofold. First of all we observed compliance of internal provisions of commercial banks with requirements proceeding from legislative acts. Compliance with requirements was observed in the context of three groups of requirements:

- customer notification in the case of investment advisory;

- $\quad$ assessment of investment service suitability and relevance (for a client);

- mitigation and prevention of conflicts of interests.

Secondly, as (according to theoretical standpoints) the quality of service is measured on the basis of customers' perception and evaluation, then it was necessary to collect evaluations and feedback from individuals who had recently consumed investment consulting service. In order to imitate reality in the best possible way the authors decided to organize meetings-interviews of private persons with consultants of Estonian commercial banks which had had authorization for investment consultation. Interviews were conducted during two periods - from October 3 till November 11, 2011, and from March 2 till March 15, 2012. The objectives of these interviews were to clarify how institutions with investment consultation authorization follow requirements of Securities Market Act, and assess independently and objectively from private investor's point of view the quality of investment consulting service. Opinions of potential clients regarding provided service were analyzed. Main questions authors were looking answers for dealt with assurance, reliability, access and flexibility of investment consulting service, and the level of consultants' professional skills.

In addition to authors there were eight people (so called potential clients) who were involved into organization of meetings, and participated in the study. Their task was to register to a consultation meeting with propensity to find an appropriate investment solution. Objectives of an interview were explained to participants during personal meetings with them; also instructions were distributed during the meeting. Instructions consisted of two parts - the legend of a meeting and questions to be asked from a consultant. Additional people were involved into conducting the study in order to increase its objectivity; extra reason was that without assistants the amount of work for the authors would be too burdensome.

After meetings with consultants participants were interviewed; for this purpose questionnaire elaborated by the authors of this paper was used. Also other aspects, not covered by the questionnaire, were documented. Questionnaire included issues of finding and proposing an appropriate investment solution, disclosure of relevant information, and general issues and client's appraisals.

In total the sample size consisted of 19 consultation meetings; 5 interviews were conducted by authors and 14 by other participants. Meetings were organized in several Estonian cities. In the following Table I breakdown of meetings by an institution and a city is presented. 
TABLE I: NUMBER OF VISITED INVESTMENT CONSULTANTS BY INSTITUTION AND REGION

\begin{tabular}{lcccc}
\hline Aank/Region & Tallinn & Tartu & Jõhvi & Total \\
AS Swedbank & 3 & 1 & 1 & 5 \\
AS SEB Pank & 3 & - & 2 & 5 \\
$\begin{array}{l}\text { Nordea Pank Finland Plc } \\
\text { Eesti }\end{array}$ & 2 & 1 & 2 & 5 \\
AS Danske Capital - & 1 & - & 1 & 2 \\
Sampopank & 2 & - & - & 2 \\
AS LHV Pank & 11 & 2 & 6 & 19 \\
Total & & &
\end{tabular}

There are several reasons why the final sample size was so small. A potential client in one bank could go to a consultation meeting only once as during repeated visit s/he would be transferred to the same investment consultant, and probably s/he would have entered into contract which was not the objective

The second reason is limited availability of investment consultation service even in bigger cities/towns, e.g. Tartu. In order to get larger sample we would have to engage more potential clients which was problematic as this concerns personal financial matters. Also not many people agreed to spend their spare time for visiting banks. Finally authors have to assert that investment consultation service outside capital of Estonia, Tallinn, is rather poorly available. The most handy and quick way to access investment consulting service is to register at AS SEB Pank as this is the only financial institution in Estonia that provides advisory service for private individuals all over Estonia, and which also has the most convenient registration systems.

Of course, such an approach to investment consultation quality assessment is not free of deficiencies: one can argue about possible subjectivity of participants, small sample size, poor geographical/institutional representation, the qualitative nature of study etc. Authors fully admit possible errors embedded in such an approach. Still authors think that the present study is sufficient enough to make prudent conclusions about the quality of investment consultation in Estonian commercial banks. One should not also forget that to authors' bet knowledge this is distinctively a pilot study in Estonian context.

\section{RESULTS OF EMPIRICAL ANALYSIS}

\section{A. Conformity of Commercial Banks' Internal Rules to Legal and Regulatory Requirements}

All the banks had disclosed on their websites necessary information, including customers' categorization procedure, summary of securities-related risks and fees, overview of client's securities investments and their compensation limits. All the information is reflected in rules of provision of investment services.

Although banks provide overview of risks and information related to investor protection in rules of provision of investment services, it is very important that bank's representative mentions during investment consulting that a customer should get acquainted with this information; also it is important to mention how the customer can do this. In opposite case the client in fact is not informed about all the risks with sufficient time reserve before entering into contract. Also Securities Market Act requires that investment consultants provide this information when advising clients [22]. If investment consultants do not disclose this information directly at investment advisory meeting, then bank should provide this information electronically before meeting with the client or on paper at the consulting meeting. Reference to bank's website is also a feasible solution if the bank is confident the client has the access to internet.

Despite the fact that banks inform on their websites about risks, investor protection and other compulsory aspects representatives should refer to these aspects, legislative acts before or during investment consulting, and also explain where a client can get this information. Only this way the client awareness can be assured - banks would really disclose all the necessary information, and customers would be knowledgeable about their own rights and banks' liabilities but not only after signing an agreement.

Based on analysis of public sources authors conclude that regardless of information which is electronically disclosed by banks on their websites it is not clear whether and how it is disclosed during advisory process. Also, some banks seek to transform their informing liability into clients' examination liability.

Regarding the assessment of investment service suitability and relevance it came out that all financial institutions disclosed on their websites how this process is conducted, objectives and conditions of this process were described as well. Generally, bank's risk profile questionnaire (or fill-in form) is to be filled in service halls or via internet-bank. Without getting necessary information about client's knowledge, experience in the field of investing, his/her financial condition, and investment objectives banks do not give personal investment recommendations.

Diversity of investment services from time to time may generate conflicts of interest in a financial institution, also between the financial institution and its employees or clients. According to Securities market act, in order to prevent such conflicts of interests a financial institution must employ measures' description and summary of which should be disclosed on a website of the institution. Although procedure of management and avoidance of conflicts of interests (or descriptive summary at least) is presented on the websites of all the financial institutions, majority of commercial banks did not take into account first minimum requirement of Securities Market Act which provides that one should reckon with probability that a financial institution or a relevant person (investment consultant) receives emolument or avoids financial loss on the account of his/her client. Second minimum requirement is divergence of interests of the financial institution or the relevant person from those of the client. Both situations can be described by the payout of additional pays or bonuses for each transaction or signed contract - if the investment consultant has a financial interest to sign a contract with the client then client's interests can be damaged.

Some banks pass over information disclosure responsibility to their clients, which restricts to some extent a 
client's right to receive this information in a form he/she needs. Also financial institutions do not take into account the fact that an ordinary client may not have access to internet, and he/she may not understand a legalese of disclosed documents which in some part restrains his/her right for receiving information as well. Securities Market Act prescribes that the information disclosed to a client must be presented in clear and understandable language.

In authors' opinion liable source of information is an on-paper document commented by the investment consultant. As information on websites is a subject to a constant change then later it is harder to prove that the information was presented on the website in a particular way. The best option in this situation is to inform a customer orally and in writing (on paper document), with all the information available on a website as sufficient condition.

\section{B. Private Persons' Appraisals of Investment Consulting Service}

To sum up results of the interviews the following main points can be brought out.

First of all, according to potential clients' opinion, investment consultants acted rather as investment product salespersons presenting bank's investment products. Customer's specific needs and preferences were not identified, and appropriate investment solution was not looked for. During nine meetings out of 19 consultants advertised something. Generally these were various investment products of own bank which clients did not considered as a possible solution but rather as hard sell. Besides investment products in four cases investment consultants advertised other products, such as loans, credit cards, bank accounts. Also there were cases where consultants used baits to attract clients (film festival tickets).

The most proficient consultants in the field of investment seemed to be male advisers from Sampo and Swedbank, and female advisers from LHV Pank. In their cases potential clients noted, that even if advisers didn't request to fill the questionnaire or didn't study client's personal needs or preferences, they were able to provide good investment recommendation, and answer all the questions. Also it should be noted that among 19 investment advisers only 3 were males (all of them younger than 30 years). At the same time, according to participants-interviewers males consultants provided more functional recommendation compared to females. All the male consultants recommended abstaining from investing for multiple reasons: unstable markets, client's lack of experience and young age, better alternatives compared to financial markets (e.g. real estate market).

Seven out of 19 investment consultants didn't justify or explain anyhow proposed solutions. Among them five advisers were from SEB, other two from Sampopank and Nordea bank. In remaining cases there were dialogues concerning proposed investment solutions, consultants explained thoroughly why one or another option was more suitable.

During advisory meetings it came up that in five of 19 cases clients were informed about fees and costs of investment services. Clients were informed about investor protection and protection schemes in three cases only. There are several incentives and constraints for private investors arising from taxation and legal acts - for instance, tax incentives and restrictions related to withdrawal of money in case of voluntary pension fund. Taxation was mentioned in three cases, and constraints and risks proceeding from legal only in two cases. Conditions of provision of investment services were discussed only at four meetings, and even then it was done only on rather superficial level.

At the same time potential clients claimed that in nine out of 19 times they received sufficient information. However, one must take into account that they were ordinary customers with no investment experience, lack of knowledge about legal requirements concerning investment consultation; they were not able to assess which factors should be kept in mind when making investment decisions. In this situation it is logical to assume that despite scantiness of information clients might have thought they received it in sufficient amount.

Among potential clients roughly half thought that solutions proposed by a consultant were compatible with clients objectives and risk tolerance. Five clients thought that proposed solutions did not fit, and four clients did not know whether proposed solutions were appropriate or not. This aspect may refer to the fact that investment consultants did not reasoned pretty well proposed solutions. Only in three cases out of 10, when investment service relevance and suitability for a client was assessed, clients had an opinion that proposed solution is compatible with their objectives and risk tolerance. However, it is hard to assess impartially whether those solutions were appropriate or not. This brings out one of the bottlenecks of investment consulting process: a consultant did not provide enough information about solutions, and did not explain why particular solutions were suitable. According to participants' opinion, in 10 cases out of 19 consultants were able to reason pretty well proposed investment solution, and present arguments. Solutions (and argumentation for these solutions) proposed by consultants from Danske Capital received highest evaluations.

Potential clients also expressed their opinion on aspects that irritated them or looked suspicious. Some of these aspects were following:

- investment consultant's verdancy;

- offering of inapt, unreasoned solutions;

- fewness of information and products;

- $\quad$ poor servicing, including lateness, feeling that a consultant wants to get rid off a customer;

- consultant's ignorance of situation on financial markets.

One of the most important details that potential clients accented was consultants' competence. In case of SEB Pank majority of potential clients noted they became doubtful about consultant's competence due to multiple reasons: lack of discussion between an adviser and a client; inability to answer questions and/or reason standpoints. In case of Swedbank's investment consultants participants noted that instead of consultants they had advisory meetings with bank tellers. Also, in two cases it was mentioned that consultants were replaced immediately prior a meeting which looked suspicious and questionable. 


\section{CONCLUSIONS AND PROPOSITIONS}

Based on analysis and conducted research authors conclude that investment consulting service in Estonian banks is not on a needful level for clients. Also financial institutions and their representatives do not comply with many requirements proceeding from legislative acts. Potential clients who experienced this service gave low evaluations to the quality of personal investment recommendations.

One can say that in Estonian context the objective of investment consulting service is to present bank's investment products with intention to sell; developing an appropriate investment proposal for a client abiding legislative requirements is of rather secondary importance. Authors reached that conclusion based on bottlenecks and problems detected during the study; they include:

- scanty disclosure of information during investment consultation;

- lacking of assessment of relevance and suitability of investment service before giving a personal recommendation;

- low level of competence of investment consultants;

- limited access of investment consulting service;

- deficient designation, disclosure and tracking of measures to prevent and manage risk of conflicts of interest

- $\quad$ using of baits.

It is especially vital to improve access to investment consulting service in financial institutions that have a large investment market share. In authors' opinion investment consulting service availability can be improved if a client is given possibility to register for a consultation electronically and by phone. Currently both options are offered only by couple of banks. Simplification of registration system would also help to solve problems of information, relevance and suitability assessment. Authors' propositions to improve investment consulting service are compactly presented on Fig. 2 below.

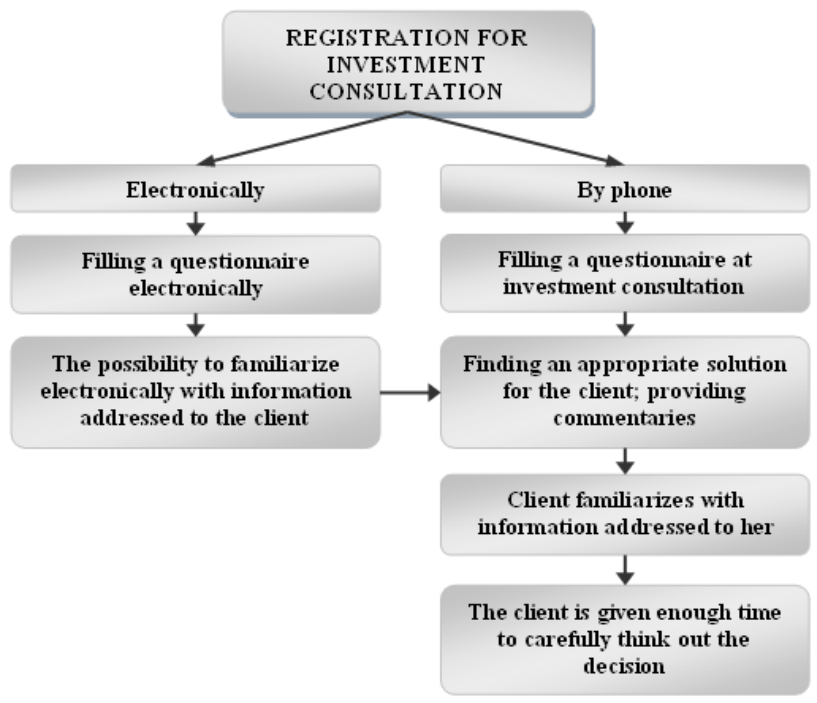

Fig. 2. Propositions for improvement of investment consultation service quality in Estonian banks.

What concerns the problem of consultants' competence then this can be solved not only by requiring higher education degree in the field of Economics or Finance but also by organizing investment trainings. In Estonia banks could employ the practice of developed financial market where people working in investment consulting have a certain qualification. Eventually this leads to the issue of cooperation between universities and commercial banks.

Consultants' remuneration system should be designed so that consultants are not paid extra fees and bonuses on monthly basis - additional remuneration could be paid quarterly; the size of additional payments should be the function of number of satisfied customers, not the function of a number/size of signed contracts. This would ground to some extent risk of conflict of interests, and prevent banks from harming client's interests. Also measures to manage and avoid conflicts of interests should be defined specifically and intelligibly; application of these measures should be also brought out in order to foster transparency of bank-client relations.

Heretofore some banks use baits when concluding a contract which is not ethical toward ordinary clients. If a bank or an asset manager wants to please a client the best way is to increase the value of client's assets in long-term.

\section{REFERENCES}

[1] More complaints submitted regarding banks. Financial Supervision Authority press release. [Online]. Available: http://www.fi.ee/?id=15346\&year=2012

[2] Sale of fund units in SEB Liquidity Fund misleading. Financial Supervision Authority press release. [Online]. Available: http://www.fi.ee/index.php?id=12332\&year $=2008$

[3] M. Golovatjuk, Statistics on Complaints and Violations Regarding Investment Consultation, Mail Exchange with Authors, April 02, 2012.

[4] M. Salu. (April 23, 2008). Investeerimisnõu: oodata ei tasu. Parem osta languse ajal. Eesti Päevaleht. [Online]. Available: http://www.epl.ee/news/majandus/investeerimisnou-oodata-ei-tasu-pa rem-osta-languse-ajal.d?id=51127205

[5] C. Grönroos, Service Marketing Theory: Back to Basics. Swedish School of Economics and Business Administration, Helsinki: OY Casa Security AB, 1998, pp. 24.`

[6] A. Parasuraman, V. A. Zeithaml, and L. L. Berry, "SERVQUAL: A Multiple-Item Scale for Measuring Consumer Perceptions of Service Quality," Journal of Retailing, vol. 64, no. 1, pp. 12-40, 1988.

[7] G. A. Hirt, S. B. Block, and S. Basu, Investment Planning for Financial Professionals, New York: McGraw-Hill, 2006, pp. 369.

[8] T. K. Liaw, The Business of Investment Banking: A Comprehensive Overview, $3^{\text {rd }}$ ed., Hoboken, New Jersey: John Wiley \& Sons, 2012, pp. 384

[9] Y. Ouyang, "A relationship between the financial consultants' service quality and customer trust after financial tsunami," International Research Journal of Finance and Economics, issue 36, pp. 75-86, 2010.

[10] M. M. Jennings, "Ethics and Investment Management: True Reform," Financial Analysts Journal, vol. 61, issue 3, pp. 45-58, 2005

[11] New rules for more efficient, resilient and transparent financial markets in Europe. [Online]. Available: http://europa.eu/rapid/press-release_IP-11-1219_en.htm

[12] L. J. Gitman and M. D. Joehnk, Fundamentals of Investing, Boston: Addison, 2002, pp. 661.

[13] R. H. Johnson and W. O. Winchell, "Educating for quality," Quality Progress, vol. 2, September, pp. 48-50, 1988

[14] S. Karapetrovic and W. Willborn, "Quality assurance in investment Services,” Managing Service Quality, vol. 9, no. 4, pp. 222-229, 1999

[15] G. D. Kang and J. James, "Service quality dimensions: an examination of Grönroos's service quality model," Managing Service Quality, vol. 14 , no. 4, pp. 266-277, 2004

[16] W. M. Pride and O. C. Ferrell, Marketing: Concepts and Strategies, Dreamtech Press, 2004, pp. 610.

[17] A. Parasuraman, V. A. Zeithaml, and L. L. Berry, "A conceptual model of service quality and its implications for future research," Journal of Marketing, vol. 49, no. 4, pp. 41-50, 1985. 
[18] J. J. Cronin and S. A. Taylor, "SERVPERF versus SERVQUAL: Reconciling-Performance-Based and Perceptions-Minus-Expectations Measurement of Service Quality,” Journal of Marketing, vol. 58, no. 1, pp. 125-131, 1994

[19] S. D. Welch, "Investment consulting and its evolving role in advising family offices," in Proc. AIMR Conference, Investment Counseling for Private Clients V, July 2003, pp. 58-65.

[20] K. M. Gounaris and M. F. Prout, "Repairing relationships and restoring trust: behavioral finance and the economic crisis," Journal of Financial Service Professionals, vol. 63, issue 4, pp. 75-84, 2009

[21] Eesti finantsteenuste turg seisuga. (Dec. 31, 2013). [Online]. pp. 35. Available: http://www.fi.ee/public/turg_seisuga_2012_12_eesti.pdf

[22] Securities Market Act. [Online]. Available: http://www.legaltext.ee/text/en/X40057K13.htm

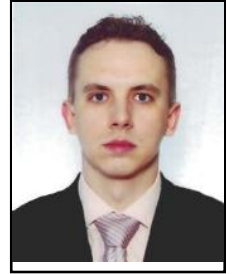

Mark Kantšukov received his MA degree from the University of Tartu and is currently working as a lecturer in Finance at the University of Tartu, Faculty of Economics and Business Administration (Estonia). His research interests lay in the field of corporate finance and investments, especially in corporate and asset valuation. he is also interested in financial modeling, behavioral finance, and financial fraud. He has published several research papers on aforementioned topics.

Maria Štšukina is a graduate of the University of Tartu, Faculty of Economics and Business Administration. In 2008 she obtained bachelor degree in Economics; in 2012 she obtained MBA degree with specialization in finance. 